INFLAMMATORY BOWEL DISEASE

\title{
Opposite evolution in incidence of Crohn's disease and ulcerative colitis in Northern France (1988-1999)
}

\author{
F Molinié, C Gower-Rousseau, T Yzet, V Merle, B Grandbastien, R Marti, E Lerebours, J-L Dupas, \\ J-F Colombel, J-L Salomez, A Cortot
}

Gut 2004;53:843-848. doi: 10.1136/gut.2003.025346

See end of article for authors' affiliations

Correspondence to:

Professor A Cortot

Registre des Maladies

Inflammatoires Chroniques de l'Intestin (EPIMAD),

Service des Maladies de

l'Appareil Digestif, Hôpital

Huriez, 2ème Est, CHR et U

de Lille, 59037 LILLE

Cedex, France; a-cortot@

chru-lille.fr

Accepted for publication

21 November 2003
Background: Northern France was characterised by a high incidence of Crohn's disease (CD) and a low incidence of ulcerative colitis (UC) according to the first inquiry undertaken in the late 1980s.

Aims: To assess the trends in the incidence of inflammatory bowel disease (IBD) over a 12 year period (1988-1999) in the same area of Northern France.

Patients: Patients living in Northern France (Nord, Pas-de-Calais, Somme, and Seine Maritime-total of 5790526 inhabitants) between 1988 and 1999 were included in the study. Case ascertainment was established according to methodology previously described.

Methods: Trends in incidence were studied using a Poisson regression model in four three year periods (1988-90, 1991-93, 1994-96, and 1997-99) adjusted for age at diagnosis and sex. Incidence rates were standardised for age with the European standard population.

Results: During 1988-99, 7066 cases of IBD were recorded $156.8 \%$ CD, 37.7\% UC, and 5.5\% indeterminate colitis). Mean annual incidence rate of CD increased from 5.2/100 000 inhabitants in 1988-90 to 6.4 in 1997-99 (adjusted p for trend $<0.001$ ). In contrast, the incidence of UC decreased from 4.2 to 3.5 (adjusted $p$ for trend $<0.001$ ). The ileocolonic subtype of $C D$ increased by $25 \%$ even though median age at diagnosis and frequency of digestive investigations were not different.

Conclusions: Contrary to what has been reported in other countries in Northern Europe, the incidence of CD increased by $23 \%$ in 12 years in Northern France while that of UC decreased by $17 \%$ during the same period. This indicates that some factors which influence IBD frequency (in both directions) are still at work in this area of Europe, and that further studies aimed at identifying these should be performed. The rising incidence of CD could enhance the burden of this disease on the public health system in France.

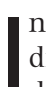
flammatory bowel diseases (IBD) including Crohn's disease (CD) and ulcerative colitis (UC) are chronic diseases of environmental, genetic, and/or immunological causes. ${ }^{1}$ Geographic or temporal variations in the incidence of IBD can help to identify causal factors. Since the 1950s, data from North America and Europe have reported a trend for an increasing incidence of $\mathrm{CD}$ and stabilisation (at a higher level) of the incidence of UC. ${ }^{2}$ In Europe, the EC-IBD population based study reported a higher incidence of UC (11.8/10 $0^{5}$ compared with $\left.8.7 / 10^{5}\right)$ and CD (7.0/10 and 3.9/ $10^{5}$, respectively) in Northern compared with Southern Europe. $^{3}$ Northern France (close to Northern Europe) was characterised by a high incidence of CD $\left(4.9 / 10^{5}\right)$ and a low incidence of UC $\left(3.2 / 10^{5}\right) .{ }^{4}$ Data on the evolution of the incidence rates of $\mathrm{CD}$ in Europe are scarce and report variable trends: some show an increase in Southern Europe ${ }^{5}{ }^{6}$ while others show stabilisation or even a decrease in Northern Europe. ${ }^{78}$ To determine how Northern France compares with these results, we report the results of a 12 year registry.

\section{SUBJECTS AND METHODS \\ Population}

Northern France had 5790526 inhabitants in the 1999 National Population census. The study area was divided into four sectors: (a) Nord, with 2554449 inhabitants and a population density of $445 / \mathrm{km}^{2}$; (b) Pas-de-Calais, with l 441422 inhabitants and a population density of $216 / \mathrm{km}^{2}$; (c) Somme, with 555479 inhabitants and a population density of $90 / \mathrm{km}^{2}$; and (d) Seine-Maritime, with 1239176 inhabitants and a population density of $197 / \mathrm{km}^{2}$. There are both rural and urban populations in these areas (ratio urban/ rural $=8.9$ in Nord, 4.5 in Pas-de-Calais, 1.4 in Somme, and 3.0 in Seine-Maritime). This region is a well defined geographical entity bordering Belgium and the North sea (fig 1). The population was stable-that is, the percentages of the population moving per year for each area were 0.8 for Nord and Pas-de-Calais, 1.1 for Somme, and 0.9 for SeineMaritime (French National Statistical Institute).

\section{Case identification and diagnostic criteria}

The methodology of the EPIMAD has been described in detail previously. ${ }^{4}$ Data concerning all patients diagnosed between 1 January 1988 and 31 December 1999 were collected by interviewing the gastroenterologists of the area $(n=238)$ practising in the private or public sector. Before the study began, all gastroenterologists were informed about the methods and aims of this work, both by letter and by meetings. Only patients who had been resident in the defined study area at the time of diagnosis of their disease were included.

Each gastroenterologist reported on any patient consulting for the first time with clinical symptoms compatible with IBD and was contacted by phone at least three times a year by an interviewer practitioner. This interviewer went to the gastroenterologist's consulting room and collected the data from the charts in a standardised questionnaire for each new case. The main data collected were: age, sex, year of diagnosis, interval between onset of symptoms and diagnosis, and

Abbreviations: IBD, inflammatory bowel disease; $C D, C$ rohn's disease; UC, ulcerative colitis; UP, ulcerative proctitis; IC, indeterminate colitis 


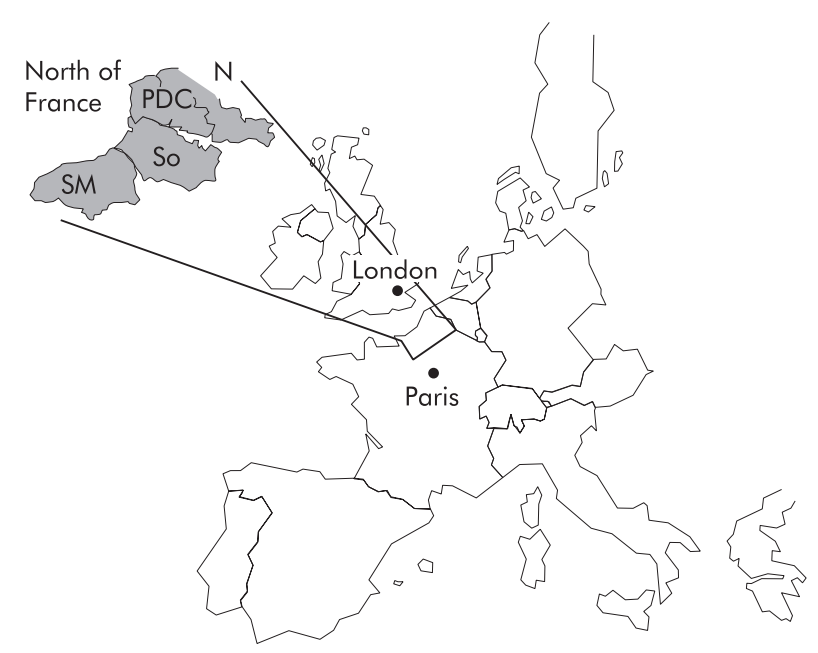

Figure 1 Geographical area of case registration. N, Nord; PDC, Pas-de-Calais; So, Somme; SM, Seine-Maritime.

clinical, radiological, endoscopic, and histological findings at the time of diagnosis.

A final diagnosis of CD, UC, or ulcerative proctitis (UP) was made by two expert gastroenterologists and recorded as definite, probable, or possible following criteria previously published. ${ }^{4}$ Patients with a case history of chronic colitis compatible with both a diagnosis of CD or UC were defined as indeterminate colitis (IC).

Patients with a case history of colitis of less than six weeks were classified as acute colitis. A systematic follow up at 18 months of patients with acute colitis was undertaken after the first visit in order to reconsider the actual final diagnosis.

\section{Quality assurance procedures}

The steering committee of the study included five academic gastroenterologists, two academic epidemiologists, one academic paediatric gastroenterologist, one private gastroenterologist, and five interviewer practitioners. This committee established written instructions for the interviewer practitioners for completing the questionnaire correctly. It also set up a framework to help the expert gastroenterologists in their final diagnosis. The committee met every three months. The aim of these meetings were, by means of test cases, to verify that the protocol was accurately followed by all interviewer practitioners and to minimise interexpert variations.

To validate the completeness of case collection by gastroenterologists, we undertook a one year validation study in the Somme region in 1989. All general practitioners $(n=498)$ and radiologists, histopathologists, surgical, and paediatric specialists $(n=36)$ received a questionnaire for notifying incident cases of IBD. If they did not reply, they were contacted by telephone. All specialists and 450 of 498 general practitioners $(91 \%)$ replied. In total, 85 cases were notified by these practitioners. In contrast, the recording system by the gastroenterologists notified only 82 cases. The three "missing" cases were declared by two pathologists and one general practitioner (one possible $\mathrm{UC}$, one possible $\mathrm{CD}$, and one probable UP). These patients had actually consulted a gastroenterologist who had forgotten to declare their cases to the interviewer practitioner. Thus the completeness of our case collection was $96.5 \%$.

\section{Analysis}

Incidence rates were calculated for the combined group of definite and probable cases (CD, UC, and IC) diagnosed between 1988 and 1999. Possible cases of IBD and acute colitis were not included in the calculation of incidence rates. Cases of UC and UP were pooled together. For each region, population data by age and sex were obtained for each year from linear interpolation of the 1982, 1990, and 1999 National Population Census. Mean annual incidence rates were calculated based on the number of patients diagnosed and the number of inhabitants for both sexes. Age standardisation was performed using the European standard population weights 15, 14, 14, 14, 14, 13, 9, 5, and 2 for each 10 year age group. ${ }^{9}$ Confidence intervals for the age adjusted rates were calculated according to the method proposed by Breslow and Day. ${ }^{9}$ Trends in incidence from 1988 to 1999 were studied in four three year periods (1988-90, 1991-93, 1994-96, and 1997-99). Trends in incidence by age at diagnosis $(0-19 ; 20-39 ; 40-59 ; 60$ years or older age groups), sex, and time period (three year intervals) were evaluated using a Poisson regression model adjusted for geographic area (Nord, Pas-de-Calais, Somme, and Seine-Maritime).

Location of disease was reported only for patients who underwent a complete bowel investigation (small and large bowel visualised for $\mathrm{CD}$ and large bowel visualised up to the caecum for UC). For CD, three locations were considered: ileocolonic, pure colonic, and pure small bowel. For UC, three locations were considered: UP, defined as involvement to the rectosigmoid junction; pancolitis, defined as involvement up to the caecum; and left sided colitis, including involvement above the rectosigmoid junction with no involvement of the caecum.

For descriptions of age at diagnosis (years) and time intervals between symptoms and diagnosis (months), median and interquartile ranges (25th and 75 th percentiles) are given. Comparisons were performed using the Wilcoxon rank sum test or the Kruskall-Wallis test.

Data analysis was performed with SAS software. ${ }^{10}$

\section{RESULTS}

\section{Patients}

During 1988-99, a total of 7066 IBD cases were recorded. There were 4013 patients diagnosed as having CD $(56.8 \%)$, 2665 with UC (37.7\%) including 904 UP (34\% of UC), and 388 with IC (5.5\%). Median age at diagnosis was 27 years (range 21-38) for CD and 35 years (range 26-47) for UC $(\mathrm{p}<0.001)$. Median interval from onset of symptoms to diagnosis was three months (range $1-12$ ) for $\mathrm{CD}$ and two months (range $1-6)$ for UC $(\mathrm{p}<0.001)$. A familial history of IBD was present in $7.3 \%$ of patients $(9.7 \%$ of CD and $4.2 \%$ of UC patients).

\section{Crohn's disease}

\section{Incidence}

Mean annual crude incidence rates of CD and UC were 6.0 and $4.0 / 10^{5}$ inhabitants, respectively. Standardised incidence rates were $5.8 / 10^{5}$ (95\% confidence interval (CI) 5.6-6.0) and $4.0 / 10^{5}$ (95\% CI 3.8-4.1), respectively. The standardised mean annual incidence rate of IC was 0.58 (95\% CI $0.52-0.64$ ), which did not change during the study period.

The incidence of CD was more elevated in women than in men: 6.4 versus $5.3 / 10^{5}(\mathrm{p}<0.001)$. The highest incidence rate was found in the age group 20-29 years for men and women (fig 2). The mean annual standardised incidence rate $\left(/ 10^{5}\right)$ increased from 5.2 in 1988-90 to 6.4 in 1997 (fig 3). The rise in incidence was particularly high in the 20-29 year age group and was similar for men and women and in the four regions (table 1). The female/male ratio was 1.2 and did not change over the time period.

\section{Disease manifestations (table 1)}

At diagnosis, colonoscopy was initially performed in $92 \%$ of CD patients, a small bowel follow through $x$ ray in $81 \%$, while 


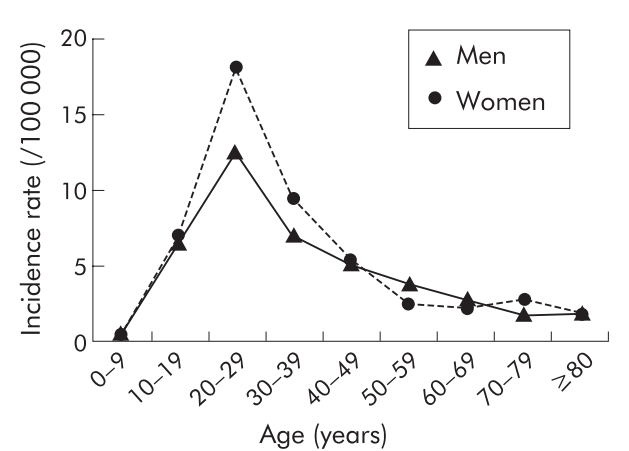

Figure 2 Incidence rate of Crohn's disease by sex and age (Northern France 1988-99).

a complete (both large and small bowel) investigation was performed in $76.7 \%$ of patients; this proportion did not change over the 12 years. An ileocolonic location was observed in $60.7 \%$ of patients, pure colonic in $18.7 \%$, and pure small bowel in $20.6 \%$. Perineal involvement was present in $18.3 \%$ of patients, and upper digestive lesions compatible with CD location in $36.0 \%$ (either at $x$ ray or endoscopy). During the study, the frequency of ileocolonic involvement increased whereas that of colonic involvement decreased. Median age of patients with an ileocolonic location was 24 (19-33) years at diagnosis, for pure small bowel median age was $27(21-37)$ years, and for pure large bowel it was $30(22-$ $42)$ years $(p<0.001)$.

\section{Ulcerative colitis \\ Incidence}

UC was more common in men $\left(4.6 v 3.4 / 10^{5} ; \mathrm{p}<0.001\right)$. The highest incidence rate was found in the age group 2029 years, 30-39 years for women, and plateaued from 20-29 to 50-59 years, decreasing more gradually for men (fig 4). The mean annual standardised incidence rate $\left(/ 10^{5}\right)$ of UC decreased from 4.2 in 1988-90 to 3.5 in 1997-99 (fig 3). The reduction was observed mainly in the 40 year and older age groups. The decrease was similar in men and women; the

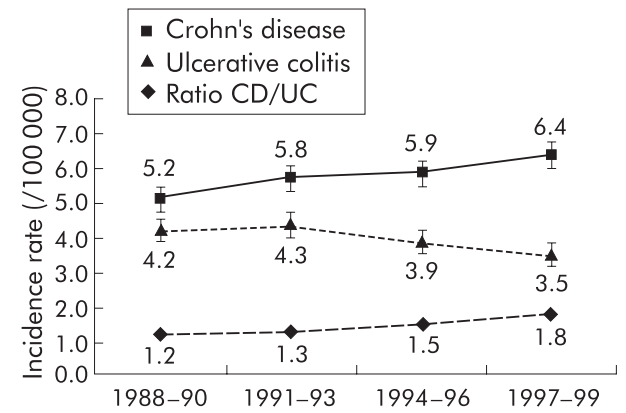

Figure 3 Trends in standardised incidence ( $95 \%$ confidence interval) of Crohn's disease (CD) and ulcerative colitis (UC) (Northern France 198899).

female/male ratio remained stable at 0.7 during the whole period (table 2).

\section{Disease manifestations (table 2)}

The interval between onset of symptoms and diagnosis shortened: from $79.3 \%$ of patients diagnosed within nine months of symptom onset in $1988-90$ to $85.2 \%$ in $1997-99$ $(p=0.05)$. A colonoscopy was performed in $99.1 \%$ of patients, and was total (up to the caecum) in $70.7 \%$, not differing among the four age groups. The proportion of patients who underwent a colonoscopy did not change during the 12 years but the proportion of total colonoscopy sharply increased from $66.5 \%$ in $1988-90$ to $78.9 \%$ in $1997-99$ $(\mathrm{p}<0.001)$. Among patients having had a total colonoscopy, $30 \%$ had proctitis, $17.5 \%$ pancolitis, and $52.5 \%$ left sided colitis, and this was similar in men and women. At diagnosis, pancolitis was more frequent in the age group 0-19 years, affecting $28 \%$ of patients compared with $18 \%, 13 \%$, and $18 \%$ in the 20-39, 40-59, and 60 year or older age groups. In contrast, left sided colitis was more frequent in older patients: $63 \%$ in the 60 year or older age group compared with $53 \%, 51 \%$, and $50 \%$ in the $0-19,20-39$, and $40-59$ year age groups. Although the frequency of pancolitis tended to rise, no significant modification of location at diagnosis was detected.

Table 1 Trends in incidence and manifestations of Crohn's disease (Northern France 1988-99)

\begin{tabular}{|c|c|c|c|c|}
\hline & $1988-90(n=793)$ & $1991-93(n=1030)$ & $1994-996(n=1054)$ & $1997-99(n=1136)$ \\
\hline \multicolumn{5}{|l|}{ Standardised incidence rate $\left(/ 10^{5}\right)(95 \% \mathrm{Cl})^{*}$} \\
\hline All $(n=4013)$ & $5.2(4.8-5.5)$ & $5.8(5.4-6.1)$ & $5.9(5.5-6.2)$ & $6.4(6.0-6.8)$ \\
\hline Men $(n=1789)$ & $4.4(4.0-4.9)$ & $5.6(5.1-6.1)$ & $5.3(4.8-5.8)$ & $5.7(5.2-6.2)$ \\
\hline Women $(n=2224)$ & $5.9(5.3-6.4)$ & $6.0(5.4-6.5)$ & $6.4(5.9-6.9)$ & $7.1(6.6-7.7)$ \\
\hline Nord $(n=1782)$ & $4.7(4.2-5.1)$ & $5.5(5.0-6.0)$ & $5.8(5.2-6.3)$ & $6.4(5.8-6.9)$ \\
\hline Pas-de-Calais $(n=1149)$ & $6.2(5.5-7.0)$ & $6.6(5.8-7.3)$ & $6.0(5.3-6.8)$ & $7.5(6.7-8.3)$ \\
\hline Somme $(n=524)$ & $6.3(5.1-7.5)$ & $8.2(6.8-9.6)$ & $8.3(6.9-9.7)$ & $8.0(6.6-9.3)$ \\
\hline Seine-Maritime $(n=558)$ & $3.1(2.1-4.1)$ & $4.3(3.7-5.0)$ & $4.9(4.2-5.6)$ & $4.5(3.8-5.1)$ \\
\hline \multicolumn{5}{|l|}{ Symptoms $(\%)(n=4013)$} \\
\hline Diarrhoea & 67.0 & 71.0 & 68.2 & 69.8 \\
\hline Blood in stools & 36.4 & 32.6 & 33.3 & 34.6 \\
\hline Abdominal pain & 78.3 & 80.8 & 84.2 & 79.9 \\
\hline Fever & 33.1 & 30.9 & 30.7 & 26.1 \\
\hline Extradigestive symptoms & 15.6 & 14.6 & 10.9 & 13.4 \\
\hline Anoperineal & 16.5 & 16.1 & 13.5 & 15.1 \\
\hline Age at diagnosis $(y) \dagger$ & $26(20-38)$ & $27(21-38)$ & $27(21-39)$ & $27(20-38)$ \\
\hline Interval before diagnosis (months) $\dagger$ & $4(1-12)$ & $3(1-12)$ & $3(1-9)$ & $3(1-9)$ \\
\hline Complete digestive investigation $\ddagger(\%)(n=4013)$ & 79.8 & 76.0 & 73.7 & 77.9 \\
\hline \multicolumn{5}{|l|}{ Location (\%) $(n=3056)$} \\
\hline Small bowel & 21.6 & 19.0 & 20.6 & 21.2 \\
\hline Large bowel & 26.4 & 20.9 & 15.7 & 14.0 \\
\hline lleocolonic & 51.9 & 60.1 & 63.8 & 64.8 \\
\hline \multicolumn{5}{|c|}{$\begin{array}{l}\text { *Standardised for European Population ( } 95 \% \text { confidence interval (CI)) } \\
\text { †Values are median (range } 25 \text { th-75th percentiles). } \\
\ddagger \text { Both small and large bowel }\end{array}$} \\
\hline
\end{tabular}




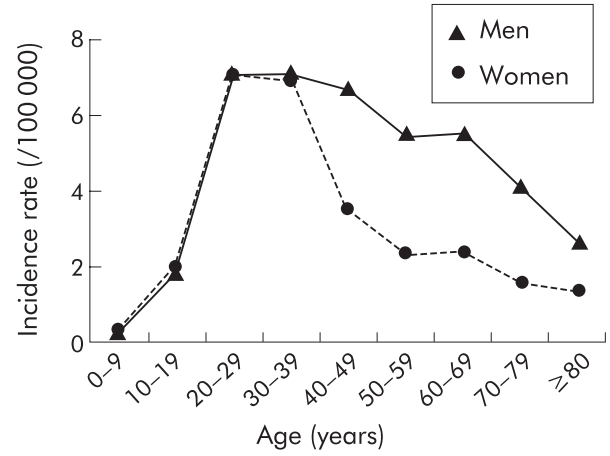

Figure 4 Incidence rate of ulcerative colitis by sex and age (Northern France 1988-99).

\section{$\mathrm{CD} / \mathrm{UC}$ ratio}

A rise in the $\mathrm{CD} / \mathrm{UC}$ ratio was observed (fig 3 ) for both sexes, each age group, and each region. This ratio, initially less than 1 only in men and in Seine-Maritime, reached 1 or more for all groups in the last period 1997-99 (from 0.9 in 1988-90 to 1.4 in 1997-99 for men; from 0.8 to 1.2 for Seine-Maritime). The gap became even higher in groups where CD was already more frequent than UC (women, regions other than SeineMaritime).

\section{DISCUSSION \\ Incidence}

Increasing trend for $C D$

An important finding of this study was that between 1988 and 1999, the incidence rate of CD in Northern France increased by $23 \%$ while the incidence rate of UC decreased by $17 \%$. The incidence rate of CD in our study has reached levels comparable with those of Northern countries (table 3), being close to rates for Wales, ${ }^{11}$ Norway, ${ }^{12}$ and Minnesota ${ }^{13}$. Numerous studies have reported an increasing trend over the past 50 years..$^{5}{ }^{1114-17}$ The increasing trend was often related to increasing age at diagnosis (global increase ${ }^{515} 16$ or a higher proportion of older patients ${ }^{7}{ }^{17}$ ). This was not the case in our study in which we found a higher proportion of cases in younger patients (20-39 years), as found by Bjornsson and Johannsson. ${ }^{14}$ After a period of increasing incidence, stabilisation was described in the early 1980s. ${ }^{7813}$ In our study, the rising incidence has not reached a plateau, suggesting that unknown triggering environmental factors are still at work in Northern France.

\section{Decreasing trend for UC}

We confirm a low incidence of UC in our area, contrasting with higher rates in other countries of Northern Europe (table 3). An increasing trend in the incidence of UC was observed until the 1980s, followed by stabilisation in Europe. ${ }^{519-21}$ Two studies reported a decreasing trend in the incidence of UC, in Minnesota from 15 to 8/10 $(1973-93)^{22}$ and in Copenhagen from 15.4 to 12.3 and from 14.1 to 12.6 in women and men, respectively (1981-92), ${ }^{23}$ while two others reported an increasing trend. ${ }^{1424}$ Ascertainment bias of UC cases in our study could not explain this decrease as : (a) follow up of acute colitis and possible cases of UC, which could eventually be reclassified as UC, did not change during the study period and; (b) the proportion of proctitis location $(30 \%)$, considered a marker of case ascertainment, remained stable.

Tobacco consumption and appendectomy are well known factors decreasing the occurrence of UC while tobacco consumption increases the occurrence of $\mathrm{CD}$. However, the decreasing trend for UC, preponderant in older subjects and in men, was not in accordance with the evolution of smokers in France ${ }^{25}$ : more women and less men have been smoking since the early 1990s. Furthermore, tobacco consumption decreased in younger people (18-25 years), from 54\% in 1992 to $47 \%$ in $1999(\mathrm{p}<0.01)$ whereas the incidence of CD increased. The variations observed in the cohort between men and women could be linked to a difference in smoking cessation between men and women. In most areas, men tend to stop smoking more frequently than women. ${ }^{26}$ Future research should focus on these factors to determine their role in the occurrence of IBD.

Our study confirmed the higher incidence of CD than UC in both sexes and in each region of Northern France. Initially reported in France and Belgium ${ }^{427-29}$ in the early 1990s, a higher incidence of CD was also observed in Stockholm, ${ }^{30}$

Table 2 Trends in incidence and manifestations of ulcerative colitis (Northern France 1988-99)

\begin{tabular}{|c|c|c|c|c|}
\hline & $1988-90(n=618)$ & $1991-93(n=750)$ & $1994-996(n=677)$ & $1997-99(n=620)$ \\
\hline \multicolumn{5}{|l|}{ Standardised incidence rate $\left(/ 10^{5}\right)(95 \% \mathrm{Cl})^{*}$} \\
\hline All $(n=2665)$ & $4.2(3.9-4.5)$ & $4.3(4.0-4.7)$ & $3.9(3.6-4.2)$ & $3.5(3.2-3.8)$ \\
\hline $\operatorname{Men}(n=1495)$ & $5.0(4.5-5.5)$ & $5.2(4.7-5.7)$ & $4.3(3.9-4.8)$ & $4.1(3.7-4.6)$ \\
\hline Women $(n=1170)$ & $3.5(3.1-4.0)$ & $3.6(3.2-4.0)$ & $3.4(3.1-3.8)$ & $3.0(2.6-3.3)$ \\
\hline Nord $(n=1137)$ & $4.0(3.5-4.4)$ & $3.9(3.4-4.3)$ & $3.6(3.2-4.0)$ & $3.4(3.0-3.8)$ \\
\hline Pas-de-Calais $(n=777)$ & $4.8(4.2-5.5)$ & $5.0(4.3-5.7)$ & $4.2(3.6-4.9)$ & $4.1(3.5-4.7)$ \\
\hline Somme $(n=242)$ & $3.9(3.0-4.9)$ & $5.1(4.0-6.3)$ & $3.7(2.7-4.6)$ & $2.0(1.3-2.6)$ \\
\hline Seine-Maritime ( $n=509)$ & $3.8(2.7-4.9)$ & $4.3(3.6-4.9)$ & $4.1(3.5-4.8)$ & $3.8(3.2-4.4)$ \\
\hline \multicolumn{5}{|l|}{ Symptoms $(\%)(n=2665)$} \\
\hline Diarrhoea & 56.0 & 51.5 & 57.3 & 55.2 \\
\hline Blood in stools & 93.1 & 92.9 & 91.9 & 90.7 \\
\hline Abdominal pain & 48.9 & 50.2 & 58.2 & 55.6 \\
\hline Fever & 10.2 & 8.6 & 8.2 & 8.8 \\
\hline Extradigestive symptoms & 5.0 & 3.4 & 3.1 & 3.0 \\
\hline Perineal & 3.1 & 1.9 & 1.5 & 1.9 \\
\hline Age at diagnosis $(y) \dagger$ & $34(26-48)$ & $36(27-50)$ & $34(26-47)$ & $35(26-47)$ \\
\hline Interval before diagnosis (months) $\dagger$ & $2(1-7)$ & $2(1-6)$ & $2(1-6)$ & $2(1-4)$ \\
\hline Complete digestive investigation $(\%) \pm(n=2665)$ & 66.5 & 66.9 & 71.2 & 78.9 \\
\hline \multicolumn{5}{|l|}{ Location $(\%)(n=3056)$} \\
\hline Proctitis & 29.8 & 32.7 & 28.5 & 28.7 \\
\hline Left colon & 57.8 & 49.5 & 51.4 & 52.3 \\
\hline Pancolitis & 12.4 & 17.8 & 20.1 & 19.1 \\
\hline
\end{tabular}

*Standardised for European Population (95\% confidence interval (CI))

†Values are median (range 25th-75th percentiles).

flarge bowel up to the caecum. 


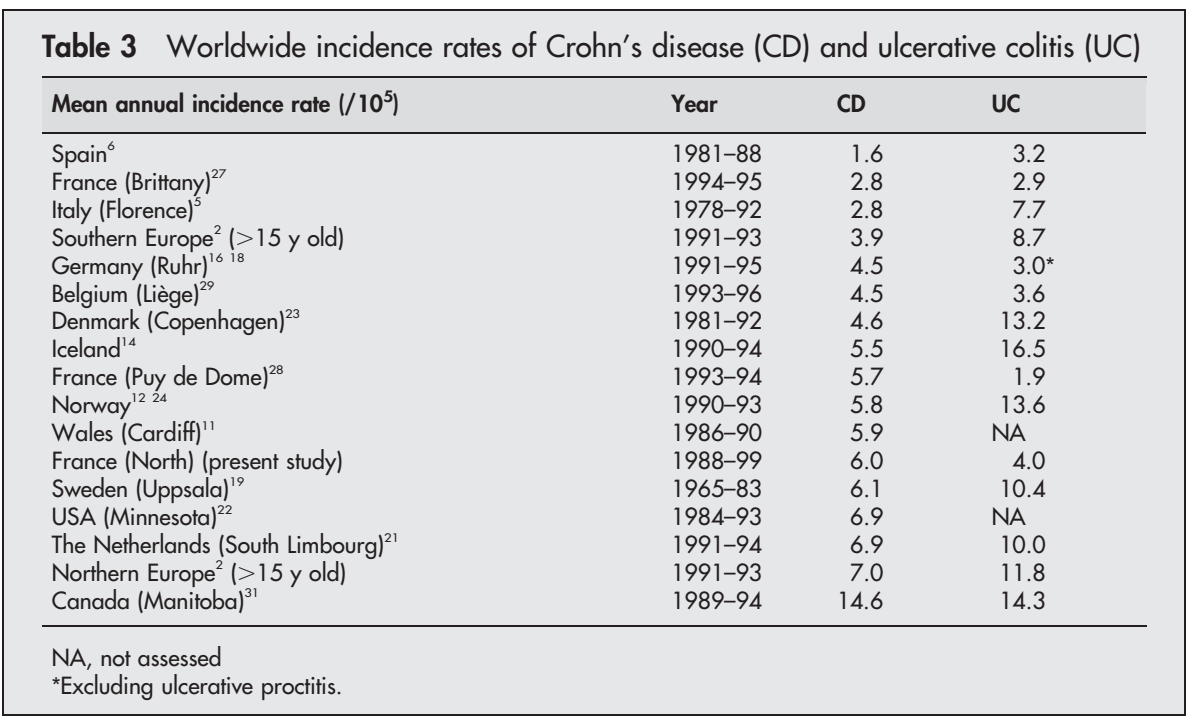

Manitoba, ${ }^{31}$ Rochester, ${ }^{32}$ Cardiff, ${ }^{11}$ and Tubingen ${ }^{33}$ The inverse ratio could be explained by the stability in incidence of UC whereas CD had increased in most developed countries. Our incidence registration, which started later than in other countries, may have started after the crossing point between the incidence of CD and UC. This is more obvious when examining the evolution of the $\mathrm{CD} / \mathrm{UC}$ ratio from 1988 to 1999 in the Seine Maritime region: UC, which was more frequent than $\mathrm{CD}$, became similar or less frequent than $\mathrm{CD}$.

\section{Disease manifestations}

The sex and age distributions of UC and CD were in accordance with previous publications. ${ }^{3} 4$

\section{$C D$ manifestations}

Some studies reported a higher and increasing trend of pure colonic location at diagnosis ${ }^{711^{14}}{ }^{34}$ : from $47 \%$ to $51 \%$ of patients with a pure colonic location at diagnosis in Iceland (1970-79 to $1990-94)^{14}$ and from $15 \%$ to $32 \%$ in Sweden (1955-64 to 1980-89). ${ }^{7}$ In contrast, we observed a predominant and increasing trend of the ileocolonic location and a decreasing trend of pure colonic location. This evolution could not be explained by modification of small bowel investigations which remained stable. There are two possible explanations. Firstly, we studied location only in patients who had undergone a complete bowel investigation (both large and small bowel visualised) which was not always reported in other studies. Secondly, median age was increased in most studies describing a higher pure colonic location $^{15} 16$ whereas in our study only the proportion of younger patients aged 20-39 years had increased, as occurred in Minnesota. ${ }^{13}$ Pure colonic location at diagnosis is less frequent in younger compared with older CD patients, and thus these modifications could be due in part to modification of the age distribution at diagnosis.

\section{UC manifestations}

In most reports proctitis location represents one third of UC patients and pancolitis is the less frequent location at diagnosis. $^{14212935}$ Recent studies reported an increase in distal colitis locations, especially proctitis, ${ }^{20}{ }^{36}$ whereas pancolitis remained stable. ${ }^{20}$ Tysk and Janerot assigned these modifications to better awareness of gastroenterologists to symptomatic patients. In our study we did not find an increase in distal locations (neither left sided colitis nor proctitis). The slight non-significant increasing trend of pancolitis location may be related to the increase in complete colonoscopy investigations (from $66.5 \%$ to $78.9 \%$ of patients).
In conclusion, we showed that in an area characterised by a high incidence of CD and a low incidence of UC, the trend remains towards a continuing increase in the incidence for $\mathrm{CD}$ and decrease for UC. This suggests that factors which influence the frequency of IBD (in an opposite direction for CD and UC) remain active, at least in this part of Europe, and offer an exciting opportunity to study them with a reasonable chance of success.

\section{ACKNOWLEDGEMENTS}

The authors thank the interviewer practitioners who collected the data: B Lemaire, N Guillon, M Inglard, I Rousseau, N Wauquier, P Fosse, M Lecomte, D Panis, L Yzet, C Dias, and S Richon. We also thank Dr Cyrus Tamboli for a thorough reviewing of this manuscript. EPIMAD is organised under an agreement between the Institut National de la Santé et de la Recherche Médicale (INSERM), the Direction Générale de la Santé (DGS), and the Institut National de Veille Sanitaire (InVS), and is also supported by the François Aupetit Association, the Ferring Laboratories, IRMAD (ASTRA Company), the Observatoire Régional de la Santé du Nord-Pas-de-Calais, the Caisse Régionale d'Assurance Maladie de Nord Picardie, and the CHRU de Lille.

We thank all the gastroenterologists and specialists who participated in this study: André JM, Antonietti M, Armand A, Aroichane I, Aubet JP, Auxenfants E, Barbry B, Bardoux N, Baron P, Baudet A, Bazin B, Bebahani A, Becqwort JP, Benet V, Benguigui C, Ben Soussan E, Bental A, Berkelmans I, Bernet J, Bernou-Dron C, Bertot P, Biron N, Bleuet $\mathrm{M}$, Blondel $\mathrm{F}$, Bohon $\mathrm{F}$, Boniface $\mathrm{E}$, Bonnière $\mathrm{P}$, Bonvarlet $\mathrm{E}$, Bonvarlet P, Boruchowicz A, Bostvironnois R, Bouche B, Boudaillez C, Bourgeaux C, Bourguet A, Bourienne A, Bray G, Brazier F, Breban P, Brung-Lefebvre V, Burgiere P, Butel J, Canva JY, Canva-Delcambre V, Capron JP, Cardot F, Carpentier P, Cartier E, Cassar JF, Castex JF, Catteau L, Caujolle B, Cayron G, Chantre M, Charles J, Charneau T, Claerbout JF, Clergue PY, Cohen G, Collet R, Crinquette JF, Dadamessi I, Dapvril V, Davion T, Debas J, Dehont F, Delatre C, Delcenserie R, Delette O, Delgrange T, Delhoustal L, Delmotte JS, Deregnaucourt G, Descombes P, Desechalliers JP, Desmet P, Desseaux G, Desurmont P, Devienne A, Devred M, Devroux A, Dewailly A, Dubois R, Ducatillon P, Duclay J, Ducrocq B, Ducrot F, Ducrotte P, Dufilho J, Duhamel C, Dujardin D, Dupont F, Duranton Y, Elie-Legrend MC, Evrard JP, Filoche B, Finet L, Foissey D, FoutreinComes MC, Foutrein P, Frere T, Gallet P, Gamblin C, Geslin G, Gheyssens Y, Gilbert T, Godard P, Godchaux JM, Godchaux R, Goria O, Gottrand F, Gower P, Grandmaison B, Guedon C, Guillard JF, Guillem L, Guillemot F, Hanon D, Heckestweiller P, Hedde JP, Hellal H, Heyman B, Heraud M, Herve S, Hochain P, Houcke P, Ivanovic A, Janicki E, Jeu J, Jonas C, Kerleveo A, Kiriakos A, Kiriakos J, Klein O, Kornhauser R, Koutsomanis D, Laberenne JE, Laffineur G, Lannoy P, Lapchin J, Laprand M, Laude D, Lecieux P, Leclerc N, Le Couteulx C, Ledent J, Lefebvre J, Le Grix A, Lelong P, Lenaerts C, Leplat A, Leroi $\mathrm{H}$, Leroy MY, Lesage JP, Lesage X, Lesage J, Lescanne-Darchis I, Lescut J, Lescut D, Leurent B, Lhermie M, Lion A, Lisambert B, Loire F, Luciani M, Lucidarme D, Lugand J, Macaigne O, Maetz D, Maillard 
D, Mancheron H, Marti R, Martin F, Martin G, Marzloff E, MathieuChandelier C, Mauillon J, Maunoury V, Maupas JL, Mesnard B, Metayer P, Meurisse B, Meurisse F, Mirmaran X, Modaine T, Morel L, Moulin E, Mouterde O, Mudry J, N'GuyenTack R, Notteghem B, Ostyn A, Ouvry D, Panien-Claudot N, Paoletti C, Papazian A, Parent B, Paris JC, Patrier P, Paupart L, Pauwels B, Pauwels M, Petit R, Piat M, Piotte S, Plane C, Plouvier B, Pollet E, Pommelet P, Pouchain G, Prades P, Prevost A, Prevost JC, Queuniet AM, Quinton JF, Rabache A, Rabelle P, Razemon V, Reix N, Richez C, Robinson P, Rodriguez J, Roger J, Roux JM, Rudelli A, Savoye G, Schlosseberg P, Segrestin M, Seryer A, Sevenet F, Silvie J, Simon V, Spyckerelle C, Talbodec N, Thelu JL, Thorel JM, Toisin J, Tonnel J, Touchais JY, Tranvouez JL, Triplet C, Turck D, Vaillant E, Valmage C, Vanco D, Vanderbecq E, Vandermolen P, Vandevenne P, Vandewalle C, Vanhoove JP, Verbiese G, Vermelle P, Verne C, Vincendet $M$, Viot J, Voiment YM, Waeghemaecker L, Wallez JY, Wantiez M, Weber J, Willocquet JL, Wolschies E, Zellweger A, Ziade C.

\section{Authors' affiliations}

F Molinié, C Gower-Rousseau, B Grandbastien, R Marti, J-L Salomez,

Registre des Maladies Inflammatoires Chroniques de I'Intestin (EPIMAD), Service d'Epidémiologie et de Santé Publique, Hôpital Calmette, CHR\&U de Lille, 59037 Lille Cedex, France

T Yzet, J-L Dupas, Registre des Maladies Inflammatoires Chroniques de I'Intestin (EPIMAD), Centre d' Amiens, Hôpital Nord, CHR\&U de Amiens, 80054 Amiens Cedex, France

V Merle, E Lerebours, Registre des Maladies Inflammatoires Chroniques de I'Intestin (EPIMAD), Centre de Rouen, Hôpital Charles Nicolle, CHR\&U de Roven, 76031 Roven Cedex, France

J-F Colombel, A Cortot, Registre des Maladies Inflammatoires Chroniques de I'Intestin (EPIMAD), Service de Gastroentérologie, Hôpital Huriez, CHR\&U de Lille, 59037 Lille Cedex, France

\section{REFERENCES}

1 Shanahan F. Crohn's disease. Lancet 2002;359:62-9.

2 Farrokhyar F, Swarbrick ET, Irvine EJ. A critical review of epidemiological studies in inflammatory bowel disease. Scand J Gastroenterol 2001;36:2-15.

3 Shivananda S, Lennard-Jones J, Logan R et al. Incidence of inflammatory bowel disease across Europe: is there a difference between north and south? Results of the European Collaborative Study on Inflammatory Bowel Disease (EC-IBD). Gut 1996;39:690-7.

4 Gower-Rousseau C, Salomez JL, Dupas JL, et al. Incidence of inflammatory bowel disease in northern France (1988-1990). Gut 1994;35:1433-8.

5 Trallori G, Palli D, Saieva C, et al. A population-based study of inflammatory bowel disease in Florence over 15 years (1978-92). Scand J Gastroenterol 1996;31:892-9.

6 Mate-Jimenez J, Munoz S, Vicent D, et al. Incidence and prevalence of ulcerative colitis and Crohn's disease in urban and rural areas of Spain from 1981 to 1988. J Clin Gastroenterol 1994;18:27-31.

7 Lapidus A, Bernell O, Hellers G, et al. Incidence of Crohn's disease in Stockholm County 1955-1989. Gut 1997:41:480-6.

8 Munkholm $\mathrm{P}$, Langholz E, Nielsen $\mathrm{OH}$, et al. Incidence and prevalence of Crohn's disease in the county of Copenhagen, 1962-87: a sixfold increase in incidence. Scand J Gastroenterol 1992;27:609-14.

9 Breslow NE, Day NE. Statistical methods in cancer research, vol 2. Lyon: IARC, 1987:48-79.

10 SAS Institute INC. SAS/STAT user's guide, version 6.4. Cary, NC: SAS Institute Inc, 1989.

11 Thomas GA, Millar-Jones D, Rhodes J, et al. Incidence of Crohn's disease in Cardiff over 60 years: 1986-1990 an update. Eur J Gastroenterol Hepatol 1995; 7:401-5.

12 Moum B, Vatn MH, Ekbom A, et al. Incidence of Crohn's disease in four counties in southeastern Norway, 1990-93. A prospective population-based study. The Inflammatory Bowel South-Eastern Norway (IBSEN) Study Group of Gastroenterologists. Scand J Gastroenterol 1996;31:355-61.
13 Loftus EV ir, Silverstein MD, Sandborn WJ, et al. Crohn's disease in Olmsted County, Minnesota, 1940-1993: incidence, prevalence, and survival. Gastroenterology 1998;114:1161-8.

14 Biornsson S, Johannsson JH. Inflammatory bowel disease in Iceland, 19901994: a prospective, nationwide, epidemiological study. Eur J Gastroenterol Hepatol 2000;12:31-8.

15 Lee FI, Nguyen-van-Tam JS. Prospective study of incidence of Crohn's disease in northwest England: no increase since the late 1970's. Eur J Gastroenterol Hepatol 1994:6:27-31.

16 Timmer A, Breuer-Katschinski B, Goebell H. Time trends in the incidence and disease location of Crohn's disease 1980-1995: a prospective analysis in an urban population in Germany. Inflamm Bowel Dis 1999;5:79-84.

17 Kyle J. Crohn's disease in the northeastern and northern Isles of Scotland: an epidemiological review. Gastroenterology 1992;103:392-9.

18 Timmer A, Goebell H. Incidence of ulcerative colitis 1980-1995. A prospective study in an urban population in Germany. Z Gastroenterol 1999:37:1079-84.

19 Ekbom A, Helmick C, Zack M, et al. The epidemiology of inflammatory bowel disease: a large, population-based study in Sweden. Gastroenterology 1991; 100:350-8.

20 Tysk C, Janerot G. Ulcerative proctocolitis in Orebro, Sweden. A retrospective epidemiological study: 1963-1987. Scand J Gastroenterol 1992;27:945-50.

21 Russel MG, Dorant E, Volovics A, et al. High incidence of inflammatory bowel disease in The Netherlands: results of a prospective study. The South Limburg IBD Study Group. Dis Colon Rectum 1998:41:33-40.

22 Loftus EV, Silverstein MD, Sandborn WJ, et al. Ulcerative colitis in Olmsted County, Minnesota, 1940-1993: incidence, prevalence, and survival. Gut 2000;46:336-43.

23 Fonager K, Sorensen HT, Olsen J. Change in incidence of Crohn's disease and ulcerative colitis in Denmark. A study based on the National Registry of Patients, 1981-1992. Int J Epidemiol 1997;26:1003-8.

24 Moum B, Vatn MH, Ekbom A, et al. Incidence of ulcerative colitis and indeterminate colitis in four counties of southeastern Norway, 1990-93. A prospective population-based study. The Inflammatory Bowel South-Eastern Norway (IBSEN) Study Group of Gastroenterologists. Scand J Gastroenterol 1996;31:362-6.

25 Haut Comite de Sante Publique. La Documentation Française, ed. La santé en France 1994-98. Paris: Haut Comite de Sante Publique, 1998:169-79.

26 McKee SA, Maciejewski PK, Falba T, et al. Sex differences in the effects of stressful life event changes in smoking status. Addiction 2003;98:847-55.

27 Pagenault M, Tron I, Alexandre JL, et al. Incidence of inflammatory bowel diseases in Bretagne (1994-1995). ABERMAD. Association Bretonne d'Etude et de Recherche des Maladies de l'Appareil Digesif. Gastroenterol Clin Biol 1997;21:483-90.

28 Flamenbaum M, Zenut $M$, Aublet-Cuvelier B, et al. Incidence of inflammatory bowel diseases in the department of Puy-de-Dome in 1993 and 1994. EPIMICl. Epidemiologie des Maladies Inflammatoires Cryptogenetiques de I'Intestin group. Gastroenterol Clin Biol 1997;21:491-6.

29 Latour $\mathbf{P}$, Louis E, Belaiche J. Incidence of inflammatory bowel disease in the area of Liege: a 3 years prospective study (1993-1996). Acta Gastroenterol Belg 1998:61:410-13.

30 Hellers G. Crohn's disease in Stockholm county 1955-74. A study of epidemiology, result of surgical treatments and long term prognosis. Scand J Gastroenterol 1979;7:401-5.

31 Bernstein CN, Blanchard JF, Rawsthorne P, et al. Epidemiology of Crohn's disease and ulcerative colitis in a central Canadian province: a population based study. Am J Epidemiol 1999;149:916-24.

32 Stowe SP, Redmond SR, Stormont JM, et al. An epidemiologic study of inflammatory bowel disease in Rochester, New York. Hospital incidence. Gastroenterology 1990;98:104-10.

33 Daiss W, Scheurlen $M$, Malchow $\mathrm{H}$. Epidemiology of inflammatory bowel disease in the county of Tubingen (West Germany). Scand J Gastroenterol Suppl 1989;24(suppl 170):39.

34 Lapidus A. The changing epidemiology of inflammatory bowel diseases. Acta Gastroenterol Belg 2001;64:155-9.

35 Lennard-Jones JE, Shivananda S. Clinical uniformity of inflammatory bowel disease at presentation and during the first year of disease in the north and south of Europe. EC-IBD Study Group. Eur J Gastroenterol Hepatol 1997:9:353-9.

36 Stewenius J, Adnerhill I, Ekelund G, et al. Ulcerative colitis and indeterminate colitis in the city of Malmö, Sweden, 1958 to 1982. A 25-year incidence study. Scand J Gastroenterol 1995;30:38-43. 